\title{
The Status of Animals in German Idealism and its Surrounding, or the Foundation of Ecology and Animal Right
}

\author{
López-Domínguez $\mathbf{V}^{*}$ \\ Universidad Complutense, Spain
}

*Corresponding author: Dr. Virginia López-Domínguez, Universidad Complutense, Madrid, Spain.

\section{Research Article}

Volume 4 Issue 1

Received Date: February 17, 2021

Published Date: March 08, 2021

DOI: $10.23880 /$ phij-16000166

\section{Abstract}

This article analyzes the evolution of the view that German idealism has about animals from both an ontological and legal perspective. The starting point is the overcoming of Cartesian mechanism, thanks to the contributions of Spinoza and, above all, of Leibniz. Still in Kant, the radical distinction between intelligence and sensitivity, the clash between moral reason and inclinations, prevent granting rights to animals. For him, intelligence broke with nature, provoking in man a feeling of superiority over other living beings, which he put at his service. However, as philosophy softens this gap between spirit and nature, animals begin to acquire a greater presence, in a process that includes Herder and Schelling Philosophies of Nature as well as Fichte's theory of the body. Finally, Krause definitively lays the foundations for ecology and animal law.

Perhaps it is because the collective concern for the consideration of animals and their rights is relatively recent, but the truth is that the important role that German philosophy of the late 18th and early 19th centuries played in relation to this theme has almost never been mentioned. This forgetfulness may have to do with the all-encompassing monumentality of idealistic systems of thought themselves, where the relationship with animals goes unnoticed and fades in the face of the multiple connections that individuals make with the world. Perhaps the carelessness is due to the fact that idealism is usually thought of as a subjectivism or solipsism, where the nature and the scope of matter have little or no value. Or finally, the omission may be associated with the fact that Hegelian philosophy, due to its claim of absolute synthesis of previous philosophical movements, concealed all those thoughts that called into question its own idea that the only significant relationships are those that men establish between themselves. However, if we observe what were the beliefs or opinions around this issue before and after this time, the differences make it clear that something very important must have upset human estimation of animal life. Let's get ahead of the answer and say that what happened then was the foundation of ecology and animal rights.
Indeed, at the end of the seventeenth century an anthropocentric conception prevailed, expressed by Descartes in Chapter V of the Discourse on Method, which presented animals as automata. These were considered as inferior beings, without a life of their own, simple machines devoid of soul and, therefore, intelligence and feelings, incapable of making decisions or even experiencing pain. In short, they were not distinguished from things and this allowed freedom from any qualms, remorse or guilt when using them for the exploitation by human beings. This is precisely what can be perceived in the painting of hunting scenes (for example, by Rubens), where the lack of criticism, when it comes to showing the persecution and death for pure pleasure and fun, is complete. It is a "natural" custom, not artificial or conventional, which, in any case, shows the supremacy of man over the animal and the belonging to a social class, also superior, which can afford to organize a hunt with the characteristics of a party. Something similar can be concluded from still life painting -in which Flemish are undoubtedly masters-, where, along with fruits and other meats, animal carcasses are exhibited, sometimes plucked, skinned or ready for cooking and consumption, as a clear sign of economic power. 


\section{Philosophy International Journal}

The subsequent behaviors with animals seem to be very far from these procedures, for example, in Schopenhauer, who claims to love dogs more than men and bequeaths an income for the support and care of his beloved pet; or in Nietzsche, who, after watching in Turin how a coachman whips a lazy horse, embraces it crying to prevent it from being punished. In both cases, what we are interested in pointing out is that the new attitude implies a commiseration that breaks down the barrier between men and animals, puts them on the same level or -as in Schopenhauer (given his radical pessimism and misanthropy)- places the second above the first.

The philosophical process that connects with this surprising change in mentality starts in Germany from Leibniz, who maintains the Cartesian mechanism at a general level, but subjecting it to a deep criticism, which forces him to subordinate it to a purpose wanted by God, so that the world works apparently like a machine, although it is at the service of finalism. This idea is especially applicable to organic bodies. In contrast to the Cartesian theory of mechanical epigenesis, Leibniz conceives organisms as "plastic material natures" that grow and develop from a germ where divine preformation has already occurred. This means that they can never be created or manufactured by men from the inorganic, since their essence is an internal force similar to that of monads, who also develop from preformed seminal reasons. In other words, animals are divine machines and, precisely for that reason, they are not machines, they are not just automatons. The root of their movement points to the will of God and this qualitatively moves them away from things to bring them closer to men.

Thus, in a letter to Arnauld on April 30, 1687, Leibniz says: "We can probably say of animals [...] that they were alive since the creation of the world and that they will live to the end. And since generation is only a consistent change in growth, also death will only be a consistent change in decline, causing this animal to re-enter the recession of a world of tiny creatures, where perceptions are more limited" ${ }^{\prime \prime}$.

The Leibnizian vision of nature made possible at the time the rapprochement between the animal world and the human world, to which other influences are added such as the discoveries of physicists, biologists, doctors and anthropologists ${ }^{2}$, in addition to the rehabilitation in Germany

1 GW. Leibniz, G. VI, p. 544. In a letter to Burchard De Volder of June 20, 1703, Leibniz insists that his theory of preformation obeys philosophical reasons and not Leeuwenhoek's microscopic discoveries. About the Leibnizian conception of animal life, see the very interesting and well documented book by Justin Smith: Divine Machines: Leibniz and the Sciences of Life. Princeton/Oxford, Princeton University Press, 2011.

2 For example, J. F. Blumenbach, K. F. Kielmeyer, P. Camper, A. von Haller, H. A. Wrisberg, L. Daubenton, E. Tysson, G.-L. Leclerc de Buffon, C. Linneo, N. Tulp, Ch. Bonnet, G. Cuvier, C. Eschenmayer, among many others. of the philosophy of Spinoza ${ }^{3}$, who, despite its mechanism, will serve as inspiration for the study of organic life. Above all, what Spinoza contributes is the idea that nature is a divine unity (deus sive natura) animated by a single creative force (natura naturans) that feeds from within all partial and particular processes, whose external effects we can precisely appreciate (natura naturata). The combination of all these ideas will produce the first sketches of the theory of evolution and of the Naturphilosophie, for example, in J. G. Herder and J. W. Goethe.

From the conviction that there is a creator divinity of all the forces that exist in the universe, as well as the rules that govern their movement, Herder establishes a continuity between animal and human life. Man is the result of the evolution of these forces, which have gone through the different stages of development, transforming themselves from the mineral world until finally converging on the animal that is closest to him: the monkey. On the other hand, the different stages are not only traversed in the whole of nature, but the human individual goes through the various organic levels again, he is a fish, reptile and quadruped, while his embryo evolves in the womb of his mother 4 .

And yet, despite the recognition of continuity, this is an anthropocentric conception, which places man as the culmination and summit of creation, since, thanks to him, reason -which secretly guided the entire process- is revealed to become aware of its journey. And it does so when the quadruped animal manages to stand up on its two feet, detach its snout from the ground where it seeks food and direct its gaze into the distance, around itself and towards the sky. Initially, the same bodily transformations derived from bipedalism create the anthropos ${ }^{5}$ and give him a social and peaceful character 6 . But, despite its similarity to higher animals, the human body is on another level and, therefore,

3 The rehabilitation of Spinoza, considered a cursed philosopher for being a pantheist and materialist, came about as a result of the controversy between Jacobi and Mendelssohn on his supposed atheism. The Letters to Moses Mendelssohn on the Doctrine of Spinoza, where Jacobi makes it known that Lessing was a Spinozist, were published in 1785 . Herder, who edited his book Ideas for the Philosophy of the History of Mankind shortly before, was familiar with the content of the letters. and he confesses the influence of Spinoza on his work in an epistle addressed to Jacobi on February 7, 1784.

4 JG. Herder presents his theory of hominization in Ideas for the Philosophy of the History of Mankind, 1rst. Part, Book III, 6 and throughout Book IV. See my translation in the book entitled Antropología e Historia, Madrid, UCM, 2002 , p. $53 \mathrm{n}$. On the evolution of the fetus in the womb, Herder, op. cit., $1 \mathrm{rst}$, IV, 4 (Tr. p. 97).

5 JG. Herder, op. cit., 1rst, III, 6 (Tr. p. 55).

6 Cf. JG. Herder, op. cit., 1rst, IV, 6. "The truth is that the complexion of man preferably directs him towards defense, not towards attack." (Tr. p. 109). "What in the quadruped, even in the timid elephant, is mating, in him it is kiss and hug due to its structure. No animal has lips like those of man [...] the last sign of the [divine] finger of love." (Tr. p. 111). 


\section{Philosophy International Journal}

its instincts are more delicate, they have lost intensity and, with it, its bestial character ${ }^{7}$.

Moreover, the idea of hominization appears at a time that is still very ethnocentric, when the ignorance of Europeans about other peoples and cultures was still very great, for which there was not yet an acceptance of the unity of the different races and they doubted the inclusion of certain ethnic groups in the human species. Thus, for example, Herder's ignorance causes him to confuse pygmies with monkeys, despite discarding the division between races, a distinction that, in other philosophers, such as Voltaire and Kant, is carried out with all rigor, which to them it leads to the contempt of the natives and, above all, of the blacks, to whom they attribute an almost animal behavior and, of course, an intelligence inferior to that of whites ${ }^{8}$.

Beyond this irritating confusion, the valuation of animals is twofold and, in a sense, contradictory. On the one hand, they are recognized as brothers whose ancestors coincide with those of man, that is, they are admitted as absolutely necessary members of a universal order without which the latter could never have existed. Its most positive characteristics are praised, those that result from expressing natural laws spontaneously, apart from intelligence and freedom. These latter qualities place the human being above the animal but, in turn, also disturb the harmony with his fellow humans and lead him to evil. So, for example, Herder says:

"No animal devours its fellow men out of gluttony, no animal murders another of its kind in cold blood by order of a third party. Among all animals, the creature with the most delicate organs, man, is the ultimate murderer. He can make his nature practically everything in living organizations below him, provided they are not too inferior"

\section{J. G. Herder, op. cit., 1aㅗ IV, 6 (Tr. p. 109 n.).}

8 "[...] Although the monkey and the pygmy sometimes walk or run upright, only in the human race is this way of walking constant and natural." (J. G. Herder, op. cit., 1st, III, 6, 1 (Tr. p. 55)). As an example of Voltaire's views on the matter, we read in Philosophy of History (Madrid, Hachette, p. 35): "Their round eyes, their flat nose, their always thick lips, their ears differently shaped, the frizzy hair of their heads, the very measure of their intelligence, put prodigious differences between themselves and the other species of men. And as a demonstration that they are not due to the climate in which they live, we see that black men and women transported to the coldest countries, always produce animals of the same species"; or in Essay on the Costums and Spirit of the Nations, CXCVII (Madrid, Hachette, p. 1158): "We only acquire domestic slaves among blacks. We are reproached for this trade; a people who traffic in their children is even more reprehensible than the buyer: this traffic shows our superiority; he who gives himself a master was born to have it". Regarding Kant, cf. Review of the Second Part of Herder's Work (Akademie-Ausgabe, hereinafter Ak.-Ausg., VIII, p. 58 n.) and Definition of the Concept of a Human Race (Ak.-Ausg. VIII, p. 107 n.).

9 JG. Herder, op. cit., 1rst, III, 6 (Tr. p. 55 y p. 137).
But that human configuration, so agonistic and devastating, is justified and acquires a positive meaning in the universal order, because it serves to accelerate destruction, the purpose of which is to cause the transition to the highest life ${ }^{10}$. The same physical structure of man, not completely covered with hair, lacking nails or powerful teeth, that is, its organic precariousness in comparison with animals, constitutes an incentive for the development of intelligence ${ }^{11}$. Ultimately, all nature, the entire creation, point, both on the positive side and the negative one, that of deficiencies and vices, to the development of rationality and freedom through language, to which the animal will never be gifted. In reality, between man and animals there is an insurmountable gap, a qualitative leap ${ }^{12}$, which should oblige the former, given his superiority, to guard and protect them according to a natural ethical law, that of equity and balance, which -as Herder says- is even recorded in the monster's chest, then, when it devours others, it can only expect to be devoured: "What you don't want others to do to you, don't do it yourself; whatever you want them to do to you, do it too"13.

A similar gap, however, exists between humanity (Menschheit) and other higher species, purely spiritual beings, perhaps angels. In this way, man's pride in being the culmination of nature is tempered in Herder's interpretation, because it is only a transitory species and not the highest, which, once the humanization process has been achieved, performs a new qualitative leap towards a higher spiritual world, that of Humanität, which transcends matter and constitutes the ultimate goal of creation in its evolutionary movement $\mathrm{t}^{14}$.

Obviously, Kant will not be able to agree with Herder's approach and will let him know in the two highly critical reviews he wrote on Ideas for the Philosophy of History of Mankind. The main points of dissension are the dogmatic character of this philosophy, which clearly leads to religion, and the idea that there is a drastic cut between the physical and the spiritual world. For Kant, nature and culture are opposed. This makes him reprove evolutionism and severely reject the validity of the use of the analogy

$10 \quad$ Ibid., p. 137

11 On the anthropology of precariousness, cf. J. G. Herder, op. cit., 1rst, IV, 4 (Tr. p. 99 n.).

12 "What greater desecration would it be human words with half human reason in the mouths of capricious, rude monkeys and animals that could imitate them -as I have no doubt-! Terrifying mix of almost human sounds and simian thoughts! No, divine speech should not be lowered so much, and the monkey was mute, more mute than other animals, while even the frog and lizard have their own sound. "JG. Herder, op. cit., 1rst, IV, 3 (Tr. p. 95).

13 JG. Herder, op. cit., 1rst, IV, 6 (Tr. p. 117).

14 J. G. Herder, op. cit., 1rst, V, 6 (Tr. p. 141 n.). 


\section{Philosophy International Journal}

between species and even admit, in its first ethics ${ }^{15}$, that the natural is immoral, since it gives off an extreme aversion to inclinations, that is, to everything impulsive or instinctive. The physical precariousness of man, the fact that he does not have instincts so developed as animals, forces him to use his intelligence and transform himself into a social and cultural being. In short, the human being is not an animal, although it should rather be said that he only has an animal part, that which relates him to laziness and selfishness, and that his true place is found in the intellectual world, in the kingdom of ends. That means that he did not straighten up to complete and perfect his nature - as Herder thinks - but to violate it, because in him there was an "unnatural germ": that of reason. Thus, the bipedal position is contrary to the instinctual. To achieve it, man modified his anatomy and the price to pay for such an alteration was the detriment to the proper functioning of his organs through displacements, torsions and dislocations:

"The first care of nature was that man, as an animal, conserve himself and the species, and therefore the most appropriate position was the quadruped [...]; but if it had deposited in him a germ of reason, by which, in developing it, he was destined for society, he would accept as constant the position most suitable for that purpose, namely, the bipedal. Through it, on the one hand, he is infinitely superior to the animals, but, on the other, he has to content himself with the inconveniences that arise from having so proudly raised his head over his old comrades $^{\prime \prime 6}$.

However, Kant evolves from this extreme culturalism and little by little he will recognize that the true evil, which drags man to perdition, to selfishness, which generates violence and produces the dominance of some over others, has to do not both with instinctive nature and with the senses, but with intelligence, with the use that it gives to the senses and what surrounds it. Evil, then, is directly related to freedom. In The Conjectural Beginning of Human History (1786) he points out that when man discovered himself as end of nature, he managed to rise above it. That consciousness of superiority encouraged his pride and his foolishness. Not only did it allow him to put natural life at his service by justifying his slavery, but it also increased "cultural vices," those superfluous and unnatural inclinations, such as the greed for goods, the ambition for honors, and the craving for dominance ${ }^{17}$, out of

15 I am referring, above all, to Groundwork of the metaphysics of customs. In this regard, see Agnes Heller, «La primera y la segunda ética de Kant», in Crítica a la Ilustración, Barcelona, Península, 1999.

16 Immanuel Kant, Review of Peter Moscati's book "On the essential bodily difference between the structure of animals and men”, Ak.-Ausg. II, p. 425.

17 In Idea of a Universal History from a Cosmopolitan Point of view (1784), Kant mentions these three appetites as engines of human progress under the slogan that "man wants harmony and nature discord " (Ak.-Ausg. VIII, p. 15 n.). which arise, in reality, the irreconcilable differences between men and their mutual subordination:

"The fourth and final step of reason elevated man far above animal society: it consisted in conceiving (albeit obscurely) that he constituted, in its proper sense, the end of nature, so that nothing that lives on earth could challenge him for competition. The first time he said to the sheep: nature has not given you the skin that you wear for yourself, but for me, by taking it off and putting it on, man was aware of a privilege that he essentially had over all animals. In accordance with that, he was no longer a companion of them within creation, but considered them means and instruments made available to his own will, so that it could achieve its arbitrary intentions. Such an idea includes (although obscurely) the opposite thought, i. e., that man is not allowed to say something similar about any man, but must consider him as an associate who shares equally in the gifts of nature. This circumstance prepared from a far the limitations that reason should impose on the will in the future, with respect to the coexistence between men, and that are more necessary than inclination and love for the establishment of society"18.

By contrast, then, the abuse and injustice with the animals made man better guess what the relationship with his fellow men should be. The fear of being used and enslaved as an inferior being showed him, albeit obscurely, the need to impose respect and fairness among them, as well as the convenience of entering into legal relationships. And, as a consequence, in political relations, given the great human difficulty to do good spontaneously without submitting to external coercion, that is, without being directed, controlled, and even punished to do so:

"Man (even if he is free) is a creature that needs a lord. This degrades him among all animals, because they do not need any lord to keep in society. The cause lies in his freedom, in that he is not propelled by natural instinct, which standardizes all members of the species, but by whims and occurrences (or by principles) that do not provide any unity. However, this freedom is accompanied by a certain propensity to withdraw from the pattern that reason prescribes and to fall down the slope of his inclinations ${ }^{\prime \prime}$.

As a result, the moralization of the species could only be put on track towards its goal, the realm of ends, by means of law. It is precisely in this context that the consideration of animals and their relationship with humans will have to be

18 Immanuel Kant, The Conjectural Beginning of Human History, in Ak.Ausg. VIII, p. $107 \mathrm{n}$.

19 Immanuel Kant, Refl. 1500 (Ak.-Ausg. XV, pages. 785-786, frag. 172). See also Refl. 1464 (ibid., p. 644, frag. 168); Lessons on practical Anthropology (Unpublished Manuscript C. C. Mrongovius, 1785, Ak.-Ausg. XVII, p. 131 n.), and Idea of a Universal History from a Cosmopolitan Point of View, Principle VI (Ak.-Ausg. VIII, p. 15 n.). 


\section{Philosophy International Journal}

considered in all those authors who continue and deepen the moral conception of culture and history initiated by Kant, as is the case of Fichte or Krause.

Indeed, in the "Introduction" to the Metaphysical First Principles of the Doctrine of Right of 1797, Kant presents a table where the different relationships that man can establish with other beings according to their rights or obligations are typified. And he points out four possible categories: 1) with beings that have neither rights nor duties, because they are irrational; 2) with beings that do have both; 3) with beings who have obligations, but not rights; 4) with a being who has all the rights, but no obligations. In keeping with the order of presentation offered, it would be animals, other rational beings, servants or slaves, and God, respectively ${ }^{20}$. Kant makes it clear that the only relationship that can be accepted as legal is one where there is a reciprocity of rights and obligations. Consequently, this can only occur between human beings, since only they are recognized legal capacity (Rechtsfähigkeit) and are considered subjects of law. As a conclusion to this argument, for Kant there is no legal obligation to treat animals fairly and correctly. Neither is there from the moral point of view, because ethical relationships are established only between free beings. With animals you can establish bonds of affection and even feel affection for them, but never respect.

This is what can be inferred, without further ado, from the contractualist and formalist foundation of law, but -as Ignaz Bregenzer already said ${ }^{21}$ - Kant ensures a graceful way out of the impasse that leads to the categorical denial of animal rights, because he does recognize that in some cases respect can be demanded, even if it is not based on the essence of the animals themselves, but on the dignity of man. By means of reciprocal action, ethical prudence sets limits to possible abuses. According to Kant, improper acts have repercussions on the abuser, who, by committing them, puts his essence and his reputation at risk before his peers, who could hardly qualify him as being rational and recognize him as such. Of course, this observation is faded in a theory of morality and law where animals, strictly speaking, have no place.

For this to happen, we will have to wait for the Philosophy of Nature to strengthen itself. And that will occur when Schelling incorporates it into the philosophical system, as a necessary science, opposite and, at the same time,

20 Immanuel Kant, Metaphysische Anfangsgründe der Rechtslehre, in Die Metaphysik der Sitten, 1st Part, Ak.-Ausg. VI, p. 203 n.

21 Ignaz Bregenzer, Thier Ethik. Darstellung der sittlichen und rechtlichen in Beziehungen zur Mensch und Thier, awarded by the German Association for the Protection of Animals in 1888, Bamberg, 1894, p. 200. complementary to Transcendental Idealism ${ }^{22}$, starting from the idea that the foundation of nature is found in an absolute, autonomous and independent activity of the subject, which gives nature a dignity similar to that of the $\mathrm{I}^{23}$. Man will once again present himself as the highest product of nature, by which it manages to become aware of itself, after numerous and successive transformations carried out through the mineral, vegetable and animal kingdoms. In this way, the interpretive line represented by Herder in his polemic against Kant resurfaces with Schelling, but -according to the last- it differs from that one by not being dogmatic and being refined thanks to the knowledge of critical philosophy ${ }^{24}$. With this new step, on the one hand, it is possible to consider nature as a unique organism in which each member of the three kingdoms has a specific function that ensures the balance and survival of the whole. On the other hand, it shows the need of nature for man's own subsistence. And finally, by admitting that, deep down, all natural phenomena are produced by free, even though unconscious, causality, empathy and respect for the animal world become admissible. Thus, the bases for the foundation of environmentalism will be laid and the way for ethics and animal law will be opened in Karl Christian Friedrich Krause, its creator ${ }^{25}$.

Meanwhile, Fichte, of whom both Schelling and Krause were followers or disciples, uses Herders arguments to continue the line opened by Kant, for example, in his Foundations of Natural Right ${ }^{26}$. It does advancing, although ambiguously. On the one hand, unlike Kant, he admits that the constitution of the legal subject occurs with the assumption that each I makes of its own body as a field of exercise of freedom. As a result, the body area acquires a new dimension in his philosophy. It ceases to be the place where the moral faculty exercises the repression of the instincts to become a means of expression and a symbol of spirituality. In a sense, this occurs because the body itself has become spiritualized, which has been achieved by detaching it from animal functions that aspire to individual self-preservation

22 Cf. F. W. J. Schelling, «Introduction», in The System of Transcendental Idealismus, §§ 1, 2 and 3; Sämtliche Werke (= SW) II, p. 339 n.

23 Schelling says in the First Sketch of a System of Philosophy of Nature: "The philosopher of nature treats nature as the philosopher transcendental to the I. Therefore, nature itself is unconditioned for him. But this is not possible if we do not eliminate the objective being of nature. The objective being is in the philosophy of nature as little original as in the transcendental philosophy." (SW II, p. 12, note)

24 Cf. F.W. J. Schelling, Filosofical Letters on dogmatism and criticism, SW I, p. $226 \mathrm{n}$.

25 Bregenzer is the first to recognize the innovative and progressive character of Krause's philosophy on this point, for his vindication of the animal as a legal subject and the defense of its rights (Ignaz Bregenzer, op. cit., p. 208).

26 Cf. JG. Fichte, Foundation of Natural Right according to Principles of the Doctrine of Science, 1rst Part, 2nd Section, $\S \S 5$ and 6, in Fichtes Werke $=$ FW) III. 


\section{Philosophy International Journal}

and by giving it a "plant instinct" 27 , which directs all growth towards obtaining the fruit and the seed to reproduce itself, a task closer to that of rational beings insofar as it points towards the species:

"Precisely by means of this idea, it has been proved that man as such is neither the disciple of nature nor should he be. If man is an animal, he is an extremely imperfect animal and, precisely for that reason, he is not an animal. The question has often been considered on the assumption that the free spirit exists to care for the animal. But this is not so. The animal exists to transport the free spirit to the sensible world and unite it with $i t^{\prime 28}$.

The direct link of the body with freedom and spirituality make the figure of man become sacred ${ }^{29}$. Consequently, the first original right is its inviolability ${ }^{30}$. The body itself, as well as all the forces that support it, are then transformed into the only legitimate property, while the use of the rest of properties, in particular, of real estate, has to be administered by the State ${ }^{31}$. Despite the great progress that implies the acceptance of nature within man himself, the gap between the natural world and the human continues to be maintained externally. Thus, animals are not granted rights in relation to their essence, since their condition is to be determined by instinctual laws, enclosed in the circle of causality and, in that sense, they are incapable of making free decisions. However, they do deserve some juridical respect. Obviously, not by themselves, but by the fact of being the property of an individual, so that the regulation of the legal relationships that humans maintain with them is reserved to the chapter dedicated to property ${ }^{32}$.

As it happens with land, neither in the case of animals is there a criterion to determine whether they belong to a private individual, so the State must be their owner and must determine how they are used and exploited. Ultimately, it will have to regulate its dealings with them, above all, the one that emanates from their use and the benefits arising from their work, avoiding indiscriminate or arbitrary exploitation. No legislation is established for companion animals, but it is for useful domestic animals, as well as for wild animals. In the case of the former, the State allows the exclusive ownership of livestock to individuals, in addition to authorizing the

27 Ibid., § 6. "Certainly, man has plant instinct, but he does not have animal instinct in the sense indicated" (FW III, p. 81). "It is a perfect plant, but it is even more" (FW III, p. 79).

28 Ibid., FW III, p. 82.

29 Ibid., "The human figure is necessarily sacred to man" (FW III, p. 85). Note that the same phrase, but referring to animals, we will see it appear in Krause.

30 JG. Fichte, op. cit., FW III, 1rst Part, 3rd Section, Chapter 1, § 9 n.

31 JG. Fichte, op. cit., FW III, 2nd Part, 2nd Section, § 18, p. 210 n.

32 JG., Fichte, op. cit., FW III, 2nd Part, 2nd Section, §19 c, p. 223 n. appropriation of their offspring, only if the owner takes over their custody, care and feeding, but reserves the right to intervene in a number of issues that notably restrict that possession, always linked to the production of some good that is beneficial for human life. For example, it can restrict the use of animals for work (oxen, horses, among others), as well as animal substance, be it milk, leather, eggs, meat, etc. It can even set a certain number of cattle slaughter. Wild animals, on the other hand, are valued as a common good and their inclusion in a reserve is prohibited. However, it is the duty of the State to annihilate dangerous or harmful animals for man and allow hunting in order to protect crops, since the rights of agriculture precede those of any animal that does not provide any benefit. It must also promote the capture of birds and wild fishing, boosting the existence of private reserves.

As can be seen, the consideration of animals acquires a purely pragmatic tenor, it is based on their dependence on humans and on the need they have for their products. Despite the advancement made by some of Fichte's recommendations on animal law, there is no true ecological awareness in him. Neither does the idea of protecting the natural habitat or the ecosystem, which can be destroyed if the balance between species is altered. Of course, he does not feel any discomfort from the use of domesticated animals, much less from the human consumption of meat. It is true that this can be justified by the fact that, at that time, the machining of work was just beginning to take its first steps, so that the use of animals for such a purpose was still presented as inevitable. It can also be argued that vegetarianism was then a very rare doctrine. However, these explanations are not entirely convincing because, just a few years later, we will find a much stronger and more progressive position in the defense of animal rights and plant protection, precisely in his disciple.

From a very young age, Krause manifested a peculiar sensibility for animals and tried to incorporate them into his worldview in a coherent way, in accordance with the role assigned to humanity ${ }^{33}$. His system, known by the name of panentheism, collected Fichte's moral and educational ideas, synthesizing them with Schelling's intuition that in God there are two opposite spheres (nature and spirit) that find their harmonic union in humanity, whose goal is the return to the divine, that is, to the reintegration of that perfect primal unity ${ }^{34}$. In this context of appreciation of the

33 Cf. Karl Christian Friedrich Krause, Der Menschheitbund, MB, p. 250, where he recognizes his interest in the question of the relationship between men and animals since 1808 , or even earlier.

34 Krause was a disciple of both Fichte and Schelling. In Germany, his ideas had a notable impact on Fr. Fröbel's pedagogy, but his greatest influence was in Spain through his dissemination by Julián Sanz del Río and the book The Ideal of Humanity. This work was actually a translation of Krause's Urbild 


\section{Philosophy International Journal}

contribution of all areas and individuals to the divine work, Krause made a defense, without distinction, of the dignity of all living beings and, therefore, he is considered the founder of environmentalism ${ }^{35}$. He advocated for those groups that were discriminated against, forgotten or unprotected in the society of his time, so that he not only vindicated equality between men and women, but also defended the rights of children and nature.

He did it at times in an angry and sarcastic way, denouncing the hypocrisy, arbitrariness or narcissism with which empathy is handled towards other beings, especially when killing other species. He discovered that pity arises only when something belongs to one's own affective sphere, but dissolves as soon as it moves away from it. In accordance with this, he wrote in his Diary:

"Just imagine the spectacle of the cooked meat of our pet, doesn't disgust us? And yet, does the animal become something different, something better or worse, simply because it is our pet?"36

Krause's innovative anticipation is truly surprising, since he not only questioned the legitimacy of man to kill animals and use their bodies for the purpose of feeding or clothing ${ }^{37}$, but he even denounced the discriminatory use of certain linguistic expressions, which define their behaviors and they are used disparagingly when referring to human beings, such as "fressen" (to devour) and "saufen" (to suck), for which he proposed their definitive eradication ${ }^{38}$. Without a doubt, his greatest contribution consists in having granted animals the status of legal subject on the basis of a non-anthropocentric conception of rationality, in open opposition to Kant and Fichte.

der Menschheit (1811). E. M. Ureña revealed the misunderstanding in Krause, educador de la humanidad. Una biografía, without a doubt, the most relevant book in Spanish language about the life and work of this thinker. Another important theoretical milestone in Spanish Krausism was made by Francisco Giner de los Ríos, who applied his pedagogical conceptions to the Institución Libre de Enseñanza.

35 On this question in Krause and, especially, on the rights of animals, cf. (in addition to the already cited book by Bregenzer, e.g., p. 208) Peter Landau, «Die Rechtphilosophie Krauses», p. 87 n., in K. Kodalle (edit.), Karl Christian Friedrich Krause (1781-1832). Studien zur Philosophie und zum Krausismo, Hamburg, 1985; and above all Francisco Querol Fernández, La filosofía del derecho de K. Ch. F. Krause: con un apéndice sobre su proyecto europeísta, Madrid, Universidad Pontificia de Comillas, 2000, p. 196n.

36 Karl Christian Friedrich Krause, July 1820 Diary, Ausgewählte Schriften II, p. 40.

37 Karl Christian Friedrich Krause, Aphorismen zur Sittenlehre. Aus dem handschriften Nachlass des Verfassers (Leipzig, 1893), Ausgewählte Schriften III, pp. 39 n., and Der Menschheitbund, MB, p. 241. Krause proposes that the consumption of meat be completely eradicated in the alliance of humanity, goal of historical development (Der Menschheitbund, MB, p. 242).

38 Karl Christian Friedrich Krause, Der Menschheitbund, MB, p. 251
Krause's starting point is similar to that of both, since legal relations are exclusively attributed to rational beings ${ }^{39}$, but the scope of reason is expanded in an unusual way. Rational beings are those who have some self-awareness and sufficient freedom to direct their will toward an established end $^{40}$. What is unusual is that animals are granted a certain degree of consciousness and personality:

"Experience -says Krause- teaches us that, in general, animals have a free personality within the limits of the senses and the mere conceptual thought purely sensitive" ${ }^{\prime \prime 1}$.

And this means that rights are also subscribed to them ${ }^{42}$ : "Consequently, to the animal world corresponds a certain legal sphere, the one determined by the temporal conditions of possibility dependent on freedom for the development of its life, and this, insofar as these conditions are conferred on animals, but also insofar as that these themselves, for their part, contribute with their energy and production to the realization of the conditions of possibility for the development of life of other superior personal beings ${ }^{\prime \prime 3}$.

In parity with humans, animals have a sphere of freedom that must be respected, insofar as it is essential for their development and self-preservation. In accordance with this, it is mandatory to ensure their physical wellbeing, nutrition and reproduction, as well as to prevent the misuse of their birth and death ${ }^{44}$. Ultimately, their rights depend on their own essence, which does not prevent that, to the extent that animals participate with their activity in the production of the material conditions of possibility of humans, their subordination to rational beings is admitted, always within a situation of respect and justice. The principle that "humanity has the right to use animals for the performance of reasonable work and to limit their freedom in accordance with the rational end of humanity ${ }^{\prime \prime 5}$ has been judged ambiguous and therefore insufficient to implement the defense of animal rights. For example, Bregenzer criticized this principle severely more than a century ago, because, under it, any kind of humiliating

\footnotetext{
39 "Law is only a certain property of the life of rational beings", Karl Christian Friedrich Krause, System der Rechtsphilosophie, SRPh, p. 28. 40 Ibid.

41 Karl Christian Friedrich Krause, Lessons from Göttingen, VÜNR, p. 137e.

42 Who recognizes self-awareness in animals, also subscribes them rights. ibid., p. 13.

43 Karl Christian Friedrich Krause, Abriss des Systems der Philosophie des Rechtes, p. 85.

44 For example, in the System of Philosophy of Right Krause states that animals have a "right to physical well-being, freedom from pain, and necessary food," SRPh, pp. 246 and 248.

45 Ibid., p. 246.
} 


\section{Philosophy International Journal}

behavior could be legitimized ${ }^{46}$. At present, the most questioned example is in this sense, experimentation and clinical trials with animals in medical and pharmaceutical laboratories, justified by the fight against diseases in favor of the future preservation of human health

Regarding animals considered useless or less evolved, Krause claims for them a treatment similar to that offered to domestic or companion animals, whose closeness to human beings makes them the object of greater appreciation ${ }^{47}$. Regarding predators, his position is close to that of Fichte, since humanity and, more specifically, the State have the right and the legal obligation to eradicate them ${ }^{48}$. For the sake of the supposed coherence of his philosophical system, Krause assigns them the unprecedented qualification of "Unthiere" (non-animals), in order to legitimize the right to the extermination of species harmful to humans.

This somewhat arbitrary restriction on the concept of animal is the tip of the iceberg of cuts to its equitable recognition with man. In reality, Krause never thought there was a continuity between beasts and human beings, a gradation, but rather an insurmountable qualitative leap. It is one thing that animals exhibit inferior thinking, linked to sensitivity, and another one that they perform superior rational functions. Ultimately, man can never be treated like an animal and, therefore, it cannot have full legal capacity or be assumed as a subject of law in the strict sense $\mathrm{e}^{49}$. Only passive rights, innate and deductible from the condition of possibility of its nature, will be reserved to it.

Due to this situation of subordination, the human being is obliged to maintain a guardianship with animals $\mathrm{s}^{50}$, similar to that assigned to adults with respect to children. The former must grant them the rights that correspond to the latter even when they lack reason or have not yet fully developed it and, therefore, are not capable of ensuring such rights themselves ${ }^{51}$. This motive, added to the limitations that we mentioned before, mean that Krause advocates -as Querol Fernández affirms- only for an attempt to attribute

46 Ignaz Bregenzer, op. cit., p. 215.

47 Cf. Chapter entitled "Wesenvereinleben der Menschheit und Thierheit", in Karl Christian Friedrich Krause, Der Menschheitbund, MB, p. 251.

48 Karl Christian Friedrich Krause, Aphorismen zur Sittenlehre. Aus dem handschriften Nachlass des Verfassers, ASL, p. 9.

49 Karl Christian Friedrich Krause, System of Philosophy of Right, SRPh, p. 86.

50 Karl Christian Friedrich Krause, May 6, 1820 Diary, Ausgewählte Schriften II pp. 24 s. Aphorismen zur Sittenlehre. Aus dem handschriften Nachlass des Verfassers, ASL, p. 38.

51 The idea of tutelary law (Vormundschaftsrecht) appears, e. g, in Der Erdrechtsbund (ERB), p. 112: "Even those who lack reason, those who cannot express their rights, should be given such rights". rights to animals that, in the end, remains within the scope of mere protection (Thierschutz) ${ }^{52}$.

\section{References}

1. Bregenzer I (1894) Thier Ethik. Darstellung der sittlichen und rechtlichen in Beziehungen zur Mensch und Thier. Bamberg, Charleston, Nabu Press.

2. Descartes R (1998) Discourse on Method and Meditations on First Philosophy. Indianapolis/Cambridge, Hackett Publishing Company Inc.

3. Fichte JG (1971) Fichtes Werke. Fichte IH (Ed.). Berlin, Walter de Gruyter.

4. Fichte JG (2000) Foundations of Natural Right according to Principles of the Wissenschaftslehre. Neuhouser $F$ (Ed.), Baur M (Transl.). Cambridge, Cambridge University Press.

5. Heller A (1999) La primera y la segunda ética de Kant», in Crítica a la Ilustración. Barcelona, Península.

6. Herder JG (1784-1791) Ideen zur Philosophie der Geschichte der Menschheit. Riga/Leipzig, Hartknoch.

7. Herder JG (2002) Antropología e Historia (Selection of bilingual texts from Ideas for the Philosophy of History of Mankind. López-Domínguez V (Transl.). Madrid, UCM.

8. Kant I (1900-1955) Gesammelte Schriften (Königlich Preussischen Akademie der Wissenschaften, Akademie Ausgabe $=$ Ak.-Ausg.). Berlin/Leipzig, Walter de Gruyter.

9. Kant I (2007) Anthropology, History, and Education. Robert L, Guenther Z (Ed.). Cambridge, Cambridge University Press.

10. Kant I (1997) Groundwork of the Metaphysics of Morals. Mary G (Transl.). Cambridge, Cambridge University Press.

11. Kant I (2017) The Metaphysics of Moral. Mary G (Transl.). Cambridge, Cambridge University Press.

12. Krause KCF (2007-2017) Ausgewählte Schriften. Ureña EM, Fuchs E (Ed.). Stuttgart, Fromann-Holzboog.

13. Krause KCF (1893) Aphorismen zur Sittenlehre. Aus dem handschriften Nachlasse des Verfassers herausgegeben von Dr. Paul Hohlfeld und Dr. August Wünsche = ASL. Leipzig.

52 Cf. Chapter entitled «La consideración jurídica de los animales entre la reivindicación de derechos y la simple protección», in Francisco Querol Fernández, La filosofía del derecho de K. Ch. F. Krause, p. 196n. 
14. Krause KCF (1900) Der Menschheitbund, nebst Anhang und Nachträgen aus dem handschriftlichen Nachlasse von Karl Chr. Fr. Krause herausgegeben von Richard Vetter, Schuldirektor in Dresden-Löbtau = MB, Berlin.

15. Krause KCF (1874) Das System der Rechtsphilosophie. Vorlesungen für Gebildete aus allen Ständen. Verfasst von Karl Christian Friedrich Krause, herausgegeben von Karl David August Röder = SRPh, Leipzig.

16. Krause KCF (1892) Vorlesungen über Naturrecht oder Philosophie des Rechtes und des Staates. Handschriftliches Vorlesungsheft des Verfasser herausgegeben von Dr. Richard Mucken, ordentlichem Professor der Universität Dorpat = VüNR, Leipzig.

17. Krause KCF (1828) Abriss des Systems der Philosophie des Rechtes, oder des Naturrechtes. Nebst einer kurzen Darstellung der geschichtlichen Entwickelung der Begriffe des Rechtes und des Staates in den bekanntesten Systemen der Philosophie. Göttingen.

18. Krause KCF (1893) Der Erdrechstbund. An sich selbst und in seinem Verhältnisse zum Ganzen und $\mathrm{zu}$ allen Einzelheiten des Menschenheitlebens = ERB, herausgegeben von Georg Mollat. Leipzig, Otto Schulze.

19. Krause KCF (1903) Das Urbild der Menschheit. Ein Versuch von Karl Christian Fr. Krause, weiland Doktor der Philosophie und Mathematik. Aufs neue herausgegeben von Dr. Paul Hohlfeld und Dr. August Wünsche. Dritte, durchgesehene Auflage = UM, Leipzig.
20. Landau P (1985) Die Rechtphilosophie Krauses. In: Kodalle K (Ed.), Karl Christian Friedrich Krause (17811832). Studien zur Philosophie und zum Krausismo, Hamburg, pp: 80-92.

21. Jacobi H (2000) Über die Lehre des Spinoza in Briefen an den Herrn Moses Mendelssohn über die Lehre Spinozas. Hamburg, Felix Meiner.

22. Leibniz GW (1875) Die philosophischen Schriften. Gerhardt CI (Ed.), Berlin.

23. Querol Fernández F (2000) La filosofía del derecho de K. Ch. F. Krause: con un apéndice sobre su proyecto europeísta, Madrid, Universidad Pontificia de Comillas.

24. Sanz Del Río, Julián El (1871) Ideal de la humanidad. $2^{\text {nd }}$ (Edn.), (Translation of the book Urbild der Menschheit by Krause, 1811). Madrid, Carlos Bailly-Ballière.

25. Schelling FWJ (1927-1954) Schellings Werke. Müncher Jubiläumsdruck. Manfred Schröter (Ed.), München, Beck/Oldenbourg.

26. Smith J (2011) Divine Machines: Leibniz and the Sciences of Life. Princeton/Oxford, Princeton University Press.

27. Ureña EM (1991) Krause, educador de la humanidad. Una biografía. Madrid, Universidad Pontificia de Comillas.

28. Voltaire (2018) Philosophie de l'histoire. Paris, Hachette.

29. Voltaire (1859) Essai sur les moeurs et l'esprit des nations. Paris, Hachette. 